\title{
Reasoning on the Origin of the Human Language
}

\author{
Valentyn Stetsyuk * \\ (An Independent Researcher, Ukraine)
}

\begin{abstract}
To solve the problem of the origin of the human language, it is proposed to use the principle of "ontogeny recapitulates phylogeny" under the assumption that the development of the child's language to a certain extent reflects the development of the human language. Taking as a basis the first sounds pronounced by a child, phonostems are determined and used when comparing etymological complexes for several semantic fields on lexical materials of several European and Asian languages. According to the results of the comparison, the effectiveness of the used principle has been estimated.
\end{abstract}

Keywords: glottogenesis, human sounds, ontogeny recapitulates phylogeny, etymological complexes, phonostems, European, Asian, rhythm of tongue

\section{Introduction}

Before starting to talk about the problems of glottogenesis, it is needed to note that we touch its social aspect only minimally, and leave this case for specialists in the field of sociolinguistics. It should be also clarified what we mean by the word "language". The competent definition, which is agreed, as follows:

Language is primarily the aggregate of words. The word is two-sided, like a medal. One side of it is external, sounding or visible (physical), the other is internal, inaudible and invisible (psychic). The first is the sounding or writing of a word, the second is its meaning or sense... Most words denote something that exists outside the language. These are objects and phenomena of the external reality or inner world of a person, about which thoughts are expressing in the process of communication of people (Yakushin, 1985:5)

It seems obvious that the language was not be given to man from above and did not arise on its own as a finished product, but went a long way towards the gradual improvement of

\footnotetext{
* Valentyn Stetsyuk: An Independent Researcher, the Chief of Charitable Fund "Dnister-88" (Lviv, Ukraine). He is a retired lieutenant-colonel. He served in the Computer Center as a system engineer in Research Institute No. 4 of USSR Ministry of Defense. For decades he has been doing independent research in the field of ethnology which was on his own graphic-analytical method, first described in 1987 in the paper "The determination of habitats of Ancient Slavs by graphic-analytical method" in the magazine Proceedings of the Academy of Sciences of the USSR. The Series of Literature and Language. Vol. LXIV, No 1. Moscow. E-mail: valentyn_ua@yahoo.de.
} 


\section{Valentyn Stetsyuk}

the sound method of communication. However, there is another point of view, according to which the emergence of language can be explained by "divine intervention", if we agree with the thought of Chomsky about a person's "innate basis" for getting knowledge in general and language in particular (Chomsky, 1972:115). A Russian scientist expressed a similar thought to some extent:

... the formation of signs of a human language is rather a development of a quality already existing,

rather than the emergence of an absolutely new quality (Vishnyatskiy, 2002:55).

In general, the problem of the origin of the language looks very complicated, multidimensional, and it can be complicated even more if we consider the following questions simultaneously: 1) Why, where and when did human tongue emerge? 2) How did the anatomical and neuro-psychological prerequisite necessary arise for the existence of a language? 3) What is the pattern of genesis of the signs that form the language? 4) How did the syntax evolve? (cf. Nikolayeva, 1996; Vishnyatskiy, 2002; Burlak, 2007). Without reliable knowledge about the origin of man in general, it is impossible to answer these questions, and the problem should be simplified by solving it in stages.

\section{Approaches to solving the problem}

Obviously, one should start with the simplest, taking up the origin of the initial form of the language, which even the thinkers of antiquity thought about, and in the new time after the initiative of Johann Herder, the theoretical development of this topic began. By the end of the 19th century, many ideas of glottogenesis have already existed, among which were the theories of D. Tiedemann, W. Wundt, L. Noire, H. Steinthal, F. Engels and many other theorists. As Yakushin (1985:5) claimed, most philosophers believed that a primordial form of the language was created by man. Further, the philosophers' thoughts diverged and none of the theories was deemed satisfactory, and obviously, therefore, in 1866, the Parisian linguistic society refused to consider studies on the origin of language and its evolution. However, the problem was not removed from the agenda, because many scientists did not consider it completely hopeless:

The question of the origin of language, as a question not idle, but scientific, is the question of how human language occurred, what conditions created it, and it remains indifferent, whether human languages have one historical beginning or not. The solution of this question is possible with the current state of science (Fortunatov, 1956:61).

These lines were written more than 120 years ago, but no expected progress followed, although by 1975 about 15,000 works were published on this issue (Nikolayeva, 1996:79). In most cases, theorists practiced a heuristic approach to solving this fundamentally non-linear problem after analyzing the sheer volume of information about language phenomena. For example, Friedrich Engels went the same way, what put forward the idea 
of the social-class essence of language, but without possessing the necessary knowledge, he too simplified the problem. One of the apologists of the communist doctrine, Marr, developed the idea of Engels in his "New Language Theory". He and his followers in the USSR presented the development of the language as an evolution passing mainly through four stages successively replacing one another. "When a new stage is reached, the former one does not disappear completely, but continues to exist without any changes, i.e. it stops in its development" (Velmezova, 2002:94). Each of these stages reflected one of types of social relations corresponding to the level of development of production means. The languages which stayed on particular levels and stopped in their development, in opinion Soviet linguists were the following:

- Chinese and some African languages - the first stage;

- Turkic, Mongolic, and Finno-Ugric languages - the second stage;

- Caucasian and Semitic languages, so called "Japhetic" - the third stage.

The Indo-European and some other languages are at the fourth stage and continue to develop (ibid). However, the current economic situation in China completely refutes this contrived theory. Misconceptions about the existence of stages of language development led Marr to the idea of the existence between them of certain boundaries that separate distinct phenomena in different components of the language, admitting at the same time the existence of substratum elements of the previous stage. In particular, at the level of phonetics, he proposed the following initial positions for the stage study of the language:

... all the words of all languages, since they are the product of one creative process, consist of only four elements, each word composed by one or two, less often three elements; the lexical composition of any language has no word containing anything in excess of all the same four elements. These four elements are denoted by... A, B, C, D; they, previously were called by us the tribal words $S A L, B E R$, $Y O N, R O S H$, are the basis of the formal paleontological analysis of each word; without prior making of such an analysis, without decomposing a word into one, two or more of elements you cannot compare, without such analysis the comparative method is not valid (Marr, 1936).

The four word-forming elements in the language and the whole Marr's "New Language Theory" were eventually rejected by Soviet linguists despite its obvious Marxist content. However, no new idea was proposed and the problem of the origin of the language was no longer seriously dared to study, it became so difficult. The linguists for a while actually practically withdrew themselves from it:

Since the question of the origin of a language could not be eliminated from the field of scientific interests at all, it was considered to be, at best, a matter of psychologists, anthropologists, etc., which can do little useful for linguists. (Bulakhovskyi, 1975)

A brief acquaintance with the history of the attitude of linguists to the question of the origin of a language is convincing about the subjectivity of evaluation of the possibility of 


\section{Valentyn Stetsyuk}

its solution, which is depended on the level of etymological research. The attitude towards the dilemma of polygenesis or monogenesis of languages was also subjective without sufficient grounds for a final choice. Most likely, the idea of monogenesis is an inner conviction of individual scientists, which is clearly seen in Rulen (1991). However, by the end of the 20th century data were found that "eloquently evidence to the unity of origin of all modern language families of the world" (Melnychuk, 1991:28). This statement implied a solution to the question of the origin of a language in favor of one common ancestor. This though did not develop in the following years and the idea of the monogenesis of the language was premature.

The failure of linguists to be productively engaged in the issue of the origin of language is a manifestation of the general crisis not only of linguistics, but also of the entire body of the humanities. Awareness of this crisis gives grounds to the generation of so-called "postmodernist" scientists to question the "fundamental principles of the science of modern times". With this tendency Marr suddenly becomes relevant "as a forerunner of the postmodern approach to language and other phenomena" (Alpatov, 2006:14).

This is not the place to look deeply at the causes of the crisis in linguistics, but one of them is the neglect of exact research methods. However, their use and, in particular, the graphic-analytical method, can provide linguists with new material for considering the problems of glottogenesis by an empirical method, and not in an ontological sense, as most philosophers have done so far. According to Vernadskiy (2004:15), an empirical generalization "does not differ of a fact established scientifically".

The use of the graphic-analytical method allowed localizing the formation of the primary dialects of the Nostratic languages in the region of the Armenian Highlands and the nearest area (Stetsyuk, 1998). Presumably, the formation of Sino-Tibetan languages went off in the same places, the Caucasian languages arose in close proximity. The insignificant dimensions of this territory make it possible to say that all these languages belong to the same phonetic field. Therefore, the main sounds of their languages should be the same or, at least, very close. This must be borne in mind when recreating the patterns of the initial stage of glottogenesis.

An assumption exists about metaphoric nature of the human proto-language (Nikolayeva, 1996:81). This overly general thought is difficult to develop in a particular direction. Theories based on this assumption are more or less poetic. Most likely, one should not delve into psychology, but retrospectively imagine possible features of the proto-language. Going in such way we come to the question of the origin of the primary linguistic signs. There are two points of view on this point.

One of them is that they initially had a verbal-sound character and grew out of various kinds of natural vocalizations characteristic for our distant ancestors, while the other assumes that sound 
language was preceded by a gesture language (Vishnyatskiy, 2002:55).

However, since human tongue developed along the path of improving sound signals, the question of gesture language is narrower in nature and it did not determine the further development of the language, although it took part in this development.

\section{The first human sounds}

Certain facts for recreating the first sounds made by man are given by comparison of the sounds of those languages, the development of which can be traced historically to a certain time limit, with the sounds made by animals close to humans. In such way unknown for us sounds of primitive people of the intermediate stage of human evolution could be restored. The hypothetical sounds obtained in this way will be the basis for further conclusions, but the implementation of such method is the most difficult task:

The question of the origin of language rests primarily on the origin of the sound side of words and

tongue, their semantic side is more often than not associated with thinking or external action and therefore seems less mysterious (Yakushin, 1985:5).

The nature of sounds at an early stage of language development may be visible by phonographic texts of ancient times left by modern man (neoanthrop) on solid materials. There is no reason to talk about verbal communication between paleoanthropes (Neanderthals), because the construction of their larynx did not allow articulating vowel sounds, and the structure of the brain did not provide the possibility of abstract thinking (Smirnov, 1997:6). At present, it seems an undeniable monophyletic theory, according which modern man is descended from one type of humanoid animals somewhere in one place of Africa. Accordingly, all the languages of the world had to undergo similar processes of formation connected with the common peculiarities of the articulation apparatus and human mental activity. Thus, ideas about the world around were associated with their reflection in a language form in a similar way.

Following Wilhelm Wundt, when they were born, languages did not have parts of speech, signs (predicates) of observed objects and phenomena were the main form of manifestation of the emerging feelings. Based on predicates, roots of new words arose and judgments were formed (Yakushin, 1985:51). The peculiarity of the creation of new words was that in this process "morphology in its modern sense was absent; the only type of word creating was putting together of roots, i.e., the combination of two root words into one complex whole" (Andreyev, 1986:4). Obviously, root words originated from sound signals and intonation, gesticulation, and other possible means, for example, order, repetition, and the accent of individual sounds refined the logical connection between them. Initially, the sound signals were supposed to be ideophones, the meaning of which somehow corresponded to the sound, although this connection is almost absent in modern languages. 


\section{Valentyn Stetsyuk}

For a long time, there were adherents of phonetic symbolism who defended opinion, supposedly separate sounds, and even more so, their combinations are endowed with a semantic or expressive character. In 1930, English linguist John Rupert Firth called such sounds and sound combinations phonostems. Observation of the communication of people can convince that the phonostems are understandable by the interlocutor without explanation. For example, sounds $m$ and $n$ are understandable to people of different linguistic affiliations as a denial, especially when they are accompanied by shaking their heads in different directions. The same sound $m$ can be understood as "I", "my", "me" if accompanied by nods of the head. Stop consonants demanded a one-time gesture that could point to another person or an object. Then sounds $d h, t h, d, t$ with a single upward movement of the head could mean "you", "your", "that", "there". Gradually, it became clear to people that the connections between sounds and their meaning clarified with the help of word creation by combining some limited set of sounds that a person possesses. The simplest sounds were vowels, which remained virtually unchanged until our days, and, as in our days, their pronouncing was accompanied by the expression of emotions reflected on the face. Consonants in combination with vowels began to develop to identify specific objects.

\section{The principle "ontogeny recapitulates phylogeny"}

The idea of the first consonants arises at observing the development of the child's tongue, in which sounds emerge naturally (primarily, the labial consonants). If we proceed from the principle of Haeckel "ontogeny recapitulates phylogeny", then the evolution of the human language should be similar to the development of the child's tongue from the moment of its birth. The importance of observing the development of a child's tongue for the reconstruction of language evolution is long known:

... specialists in children's tongue believe that children's language develops independently within

certain time limits. Therefore, we can assume, taking into account the concept of hereditary or generic memory adopted by psychologists, that the first manifestations of linguistic ability somehow characterize the process of the emergence of language (Yakushin, 1985:66).

There is, however, a different view of the meaning of the study of children's tongue for the restoration of the historical process of language development. Paedomorphosis theory, built on the study of the development of a child's speech, suggests that human languages consistently replace those features that children learn later on to those that appeared in a child's tongue earlier (Nikolayeva, 1996:83). In other words, the evolution of a language represents a movement backward, embedded in our genes, what in general contradicts most of the data on human evolution. Many scholars have criticized this theory (Lieberman, 1984; Wind, 1988), but it should be recognized that it has a rational grain. Linguistic 


\section{Reasoning on the Origin of the Human Language}

illustrations confirming the pedomorphosis theory generally relate to the field of morphology and syntax, and this can confirm the views of Chomsky on the inherent grammatical principles of man. However, observations of the sound side of children's tongue convincingly testify to the increasing complexity of the sounds uttered by the child during growing. Since we are only interested in the process of arising of the language, then the assimilation of the first and subsequent sounds by the child can help us to imagine this process.

When a child exhales with the simultaneous opening of the lips, it is easily formed the sound $p h$, which, with the participation of the vocal cords, turns into sound combination $p h a, b h a, p a, b a$. It is indicative that words having meaning "to blow", formed during exhalation, are begun by sounds $p u, b u$ - in many languages of the world (PFU. "puš-, PIE. ${ }^{*} p \bar{u}$-, " peu-, PST. "bŭ, PTM. " pū, Kor. pučha, pūl-, Jap. fusubur). When exhaling through the nose, the sound $\mathrm{m}$ and other similar phonodtema are formed. Hearing catches the difference in their sounding and can use these phonostema as audible signal when communication giving for each of them a sense according to the situation. At the same time, certain patterns are manifested in the children's babble:

The babble has a number of non-trivial features. For example, the most frequent type of syllable is the type "consonant + vowel". The same type is the single allowable in all the languages of the world). The set of possible consonants and vowels (if we keep in mind only those that repeat consistently, not taking into account unique events) is extremely limited; combinations of a consonant with a vowel within the same syllable are not accidental, but they are subject to the principle of inertia: dental consonants correlate with front vowels, back lingual with back (rounded) ones, labial consonants join with central or neutral vowels, and these correlations do not depend (or only partially depend) on adopting language. Sequences of two syllables in babbling, as a rule, are reduplications, while unreduced sequences of syllables most often begin with a labial consonant (this is due to the fact that labial consonants are easier to pronounce), while in the second syllable there is a lingual consonant (Burlak, 2007:43).

It can be assumed that according to such patterns, the birth of human speech took place when the first sounds were neutral vowels like "schwa" (ə), corresponding to the natural position of the tongue, and bilabial consonants $b, b h, p, p h, m$. To determine the first concepts fixed in the mind, related to certain sound signals, we can compare the most common and, accordingly, the most ancient words of different languages, which are beginning with rounded consonants of different types. If we select from them distinct semantic fields, analysis of which can give us grounds for some conclusions. In order to answer the question about the possibility of the common origin of all the languages of the world, such work has to be carried on the materials of as many languages as possible of the most diverse language families. 


\section{Valentyn Stetsyuk}

\section{Comparison of etymological complexes}

At one time, one suggested that the idea of restoring a primitive language by comparing existing languages is a chimera (Yakushin, 1985:66). However, it all depends on the comparison methodology, which may be different. The very process of comparing the sound composition of words of different languages of a certain semantic field will give an answer to the question of the existence of patterns in the name of the same objects by different people. Obviously, Melnychuk (1991:28) had the same idea, when he wrote, about the obtained data testifying to the unity of origin of all the languages of the world:

These data are a series of extensive phonetically correlative etymological complexes, which regularly repeated in the languages of each family, with large bundles of interconnected elementary meanings and with a specific, still not noted complex system of structural variants of the root, the same for each etymological complex.

Melnychuk based his opinion on a wide experience of working with the vocabulary of many languages when editing the etymological dictionary of the Ukrainian language and on the intuition of a great scientist. He did not make a broad comparison of such complexes, and this is beyond possibility of one researcher, but the first experience of such work was nevertheless done, and its results are presented here. In the course of this work, the following was taken into account:

... in the primitive language there existed only a very limited number of sounds and sound combinations and the range of the meanings of words was also very limited here, and these meanings would seem extremely uncertain from the point of view of a modern person with a developed language. (Fortunatov, 1956:60)

A comparison of etymological complexes was carried out for some European and Asian languages. The Turkic languages were included to European languages in accordance with the place of their formation in Eastern Europe after results of research using the graphic-analytical method. (Stetsyuk, 1998:48-52) The inclusion of the Turkic languages in the Altai family is erroneous, exactly as the idea of the first Turks as Mongoloids. Mongoloid features developed in part of the Turks after mixing them with the aborigines of Asia, with whom they came into contact after migrating from Eastern Europe to Altai. According, the comparison of Asian languages in this work was fulfilled on the materials of the Sino-Tibetan and Altai languages without Turkic. The lexical material was taken from the Global Lexicostatistical Database as well from etymological and bilingual dictionaries (see References).

\subsection{European languages}

For comparison, the lexical material of the Nostratic (Kartvelian, Turkic, Indo-European, Finno-Ugric) languages was taken and to them belonging, possibly, of North Caucasian. The analysis starts with syllable phonostems $p h ə-/ p \partial$, bhə-/bə-, mə- and their modifications. 
The search for correspondences for them in one semantic field gave the results presented below.

5.1.1 Phonostems pho-, pha-, phe-. Their possible modifications and divergences

(1) North Caucasian languages: $p a-, p e-, p i-, b a-, b e-$, etc.

Andi, Akhv., Khw., Lak baba, Avar. buba, Cham. babu, Archi buwa and others similar "mother", Abaz. pahčwi "ancestor", Ab. a-piza, Ad. paš, Chech., Ing. bačča "chieftain, leader", Ab. a-pšwma "master, host", Avar. beter, Udi bul "head", Andi beterhan, Kar. betirhan, Avar. bečed, Udi bixažuq "god”, Andi burta, Kar., Akhv. bečedo-b, Tsezi, Hin. bečedaw "rich", Ab. a-birg, Ub. bažw "old man").

This set forms the following semantic field: "mother", "ancestor", "chieftain, leader", "head", "god", "rich", "grandfather, old man".

(2) Kartvelian languages: $p a-, \mathrm{p} e-, b a-, b e-$, etc.

Georg. papa, Ming. papu "grandfather", Georg. bebia "grandmother", batoni "master, lord", berikac-i, Ming. badid-i, Laz badi "old man".

Semantic field: "grandfather, grandmother", "old man", "lord, master".

(3) Turkic languages: $p a-, p e-, b a-, b e-\rightarrow a p a-, a b a-$, etc.

Trc. apa "senior relative", aba "grandparent, ancestors", Turkm., Tat., Kyrg. baba "grandfather", Tur. baba "father, parent", Tat. babaj "grandfather, father-in-law, old man", Chuv. papaj "old man, grandfather", papay "Chuvash god", Trc., Turkm. beg, Gag., Kaz. bej, Tur. bey, Yak. bahyj, and others similar "master, lord", Gag., Turkm., Tat., Kaz. baš, Tur. baş, Uzb. boš, Yak. bas, and others similar "head", Chuv. pujan, S.-Alt., Tuv. paj, Gag., Turkm., Kaz. baj, and others similar "rich".

Semantic field: "ancestors", "grandfather, old man", "father", "lord, master", "head", "god", "rich". The latter value is associated with social status.

(4) Indo-Euriean languages: $p \bar{a}-, p \partial^{-}, p \bar{a} u-, p \bar{u}-, b a-$, etc.

Slav. baba "old woman", Ind. pitár, Av. pitar, Arm. hair ("potēr), Gr. patēr, Lat. pater "father", Ind. purắ, Alb. pa "before, formerly", Gr. peos, "kinsman, relative", Ind. Pūṣán "same god", Gr. Pān "Greek god", Slav. Perunı "Slavic god", Ind. páti-, Av. paiti"master, lord", Lith. pàts "husband", Ind. piparti "sit ober, lead", Lat. portāre "to lead, drive", pāstor "herdsman", Slav. pasti "to pasture", Toch. pās-, pāsk- "to beware, guard", Lat. polère "to be strong", Arm. hast "hard, tough", Ic. fastr, Sax. fast, OE. festi, and others similar "strong, hard".

Semantic field: "old woman", "father", "god", "kinsman, relative", "before, formely", "master, lord", "herdsman", "to defend", "to beware, guard", "strong, hard", "to lead, drive".

(5) Finno-Ugric languages: $p a-, p e-$ 


\section{Valentyn Stetsyuk}

The voiceless sounds $p a-$, $p e$ - can correspond with their voiced matches $b, b h$ absent in a Proto-Finno-Ugric protolanguage. See below.

Common semantic field for phonostems pho-, pha-, phe- in all languages includes the following concepts: "ancestors", "father", "mother", "grandfather", "old woman", "old, senior", "leader, lord", "head", "shepherd", "to take care of", "to lead, drive", "god", "rich", "strong, hard". Phonetic and semantic development of phonostems can be assumed in the direction from the meaning "ancestor" (father, mother, grandfather, woman, old) to the categories "senior, leader, lord", "god". Other derivative words took on similar meanings: "head", "herdsman", "to defend, guard", "to lead, drive". The words "rich", "strong, hard", were formed as definitions for persons of high social status or deity.

Attention is drawn to the fact that in the designation of ancestors in the male line a certain uniformity is observed, while the name of the mother even in related languages uses words from very different roots, which are often also used to refer to other adult relatives, such as "father", "(elder) sister", "woman", "grandfather", "aunt", "uncle". The most common of them are aba, ama, ana, aka, ani, ata, ava, baba, buba, dada, deda, dida, ema, ena, ima, ijo, ila, mam, mama, nana, nena, nin, non. Explaining of this diversity has to look for in psychology.

5.1.2 Phonostems bha-, bhe-. Their possible modifications and divergences

(1) North Caucasian languages: $b a-, b e-, p e-, w a-, w i-$, etc.

Chech., Ing. ber, Tab. bicir "child", Ab. a-pa, Abaz. pa, Chech., Ing. wo؟, Avar. was, Andi wošo, Bagv. waša, Tindi waha, Cham. waha, woša, Tsezi uži "son", Ab. a-pha, Abaz. pha, Ub. phja "daughter", Akhv. wacoša, Udi wičz-kar "nephew", Chech. waša, Ing. woša, Avar. wac, Andi woči, Tindi waci, Darg. uzi, Udi wiči "brother", Ab. a-wa "relatives", Ub. wišak, wašak" servant", Ab. a-wira, Udi bixesun "to be born", Ub. wišak, wašak "servant", Bagv. bižila, Hun. bigla "to grow", Ad. wici, Chech., Ing. buc, God. besi, Tsezi bix, Khw., Bezh. box, Hin. bex "grass", Avar. bačin, Cham. wuhe, Udi borzu "harvest".

Semantic field: "child", "son, nephew, brother", "daughter", "relative", "servant", "to be born, grow", "harvest", "grass".

(2) Kartvelian languages: $b a-\rightarrow b e-, b o-, w a-, w o-, o-, g w-$, etc.

Georg. važ-i, Laz bere "son", Laz bozo "daughter", Ming. bos-i "boy", Georg. ožax-i, gvar-i, Svan wodžax, gwar "family, kin", Ming. badeba "to be born", Georg. balax-i "grass".

Semantic field: "son, boy", "daughter", "family, kin", "servant", "to be born", "grass".

(3) Turkic languages: $b a-, b o-, b u-, b e-$, etc.

Turkm., Tur., Kum., Tat., Bashk., Kaz., Kyrg. bala, and others similar, Gag. pali, Chuv. papa, Tur., Karach., Balk. bebek, Tat. bäbi, Kaz. bebe, and others similar, "child", Gag. $b a \check{s} a$, Karach., Balk., Tuv. baž'a, Kaz. baža, Khak. paža, and others similar "son-in-law", 
Turkm. bažy, Tur. bacı, Yak. baxys "sister”, Tur. bulanmak, Karach., Balk. bolurga, Bashk. bulyu, Kaz. bolu, and others similar "to be", Gag., Tur. var, Karach., Balk., Tat., Kaz., bar, Yak. baar "to exist", Turkm., Tur. bitmek "to grow".

Semantic field: "child", "son, son-in-law", "sister", "to be, exist", "to grow".

(4) Indo-European: bha-, bheu-, bhōu-, bhü-, bher-, etc.

Ind. bhávati "prosper", Av. bavaiti "gets, going on", būšyeiti "appears", Alb. buronj "beginning, source, to occur", Arm. bois "shoot, grass, plant", Gr. pherma, Arm. ber "fruit, cereals, harvest", Pers. bar "fruit", Alb. ber "grass", Gr. phitu "sprout, shoot", phulon "kind, gender", Lat. fiō, fïerī "made, existing", Lith. bũ vis "being, life", Prus. buwinait "live!", Let. bûšana "being, essence", Slav. byti "to be", Ic. byrð "birth", Ind. bhrūná"embryo", Goth. barn "child", Alb. bir "son", Lith. bernas "servant".

Semantic field: "be, grow, live, exist", "occur, be born, appear", "child", "servant", "fruit, cereals", "grass, plant", "sprout, shoot".

(5) Finno-Ugric languages: $p a-, p e^{-} \rightarrow a p a-, p o-, p u-, w o-, w e-$, etc.

The words of the Finno-Ugric languages containing sounds $p, w$ can correspond to the words of other European languages, which have or had sounds $b, b h$.

Hung. apa "father", Fin. appi "father-in law", pää, Est. pea, Hung. fej, fö, Mok. pria "head", Udm. peres', pesiataj, Mari pöle, Komi pöl' "ancestor, grandfather", Mari peyyde "strong, hard", Mord. panems, Mari poktaš, Khan. pögtä "to drive". Veps poig, Mok., Erz. piji, Est. poeg, Fin. poika, Mari pu, Udm., Komi pi, Hung. fiú "boy", Fin. veikko, Sami vogk, Komi vok, Fin., Est. vend "brother", Mari pošaš, Udm. budyny, Komi bydmyny, Udm. vordyny, Komi verdny "to grow, grow up", Hung. van, Mord. ulems, Komi vövny, and others similar "to be, exist", Veps barb, vic, Fin. varpa, vitsa, Komi $u v$, Udm. $u l$ "branch, twig”, Khan. wanghi, Mansi wansin "grass", Veps vaza, Mord. vas, Fin. vasa, Mari waza, and others similar "calf".

Semantic field: "to be, exist", "father", "head", "ancestor, grandfather", "boy", "brother", "to grow, grow up", "branch, twig", "strong, hard", "to lead, drive", "grass", "calf".

Common semantic field for phonostems bha-, bhe-: "child, young animal", "son, nephew, brother", "son-in-law", "boy", "daughter", "relative", "family, kin", "servant", "to be, to exist", "to be born", "to grow", "fruit, cereals", "harvest", "grass", "branch, rod".

Some Indo-European words of the root bher- are associated with the meaning "take, carry, bring" (Slav. brati, Ind. bharati "brings", Arm. berem, Lat. fero "to carry" etc.) From other European languages, you can put under consideration only the Türkic with the meaning "give" (Turkm. bermek, Tat. birü, Kaz. beru, Uzb. bermoq etc.), nothing similar was found in other languages. Obviously, the original meaning of the word bher-was "to come, to appear", from which originate words with the meaning "child, fruit" and the like, as well as words with converse meaning "to bring, take" and "to give". 


\section{Valentyn Stetsyuk}

\subsubsection{Phonostems ma-, me-. Their possible modifications and divergences}

As it was mentioned above the single sound $m$ is used as the second-person of personal pronoun. This is true for the Kartvelian, Turkic, Indo-European and Finno-Ugric languages, but this sound is used to form a first-person personal pronoun in the North Caucasian languages (Avar. mun, Andi min, men, Bagv. me, Akhv. mene, God. min, Tsezi $m i$ etc. "you"). This difference is explained by the opposite understanding of the gesture, accompanied by the sound of $\mathrm{m}$ when communicating two people who do not know a common language. Such uncertainty is absent in the nomination of clear objects. We continue consideration.

(1) North Caucasian languages: $m a-\rightarrow m o-, m u-$, etc.

Chech. moh, Ing. muh, Tsezi mo, Bezh. mähä, Lez. maq, Ag. maw, Hin. mi, mä, and others similar "fat", God. manza "food", Darg. maha, Lez. meft, Udm. ma "brain", Chech., Ing. moz "honey", Ing. mäq, Tsezi magalu "bred", Ad. meađi, Kab. međ "sheep", Lez. mirg, Ag. murx, Rut. mix “deer".

Semantic field: "fat", "food", "brain", "bread", "honey", "sheep", "deer".

(2) Kartvelian languages: $m a-, m e-, b h a-$, etc.

Ming. manger- $i$, Geotg. marcval-i "grain", Svan manāš "rye", mengre "fleshy", Ming., Laz bža "milk", Georg. mosaval-i, Ming. monari-i "harvest", Georg. maril-i "salt".

Semantic field: "harvest", "grain", "rye", "milk", "salt".

(3) Turkic languages: $m a-, m e-\rightarrow b a-, b u-, b u l-$, etc.

Trc. mey "food", Gag. maja, Turkm., Tat., Kaz., Kyrg. maj, and others similar "fat, brain”, Turkm., Kaz., Kyrg. maral, and others similar "deer”, Tat. bolan, Kaz., Uzb., Kyrg. bulan, Chuv. pălan "deer", Trc. bulan "elk", Tur., Turkm., Tat., Kaz., Kyrg. bagir "liver", Gag. börek, Turkm. böwrek, Tur. böbrek, Kaz. büjrek, Kyrg. böjrok "kidneys", Trc. menilä- "to eat brain", meji, Chuv. mimĕ, Tur. beyin, Karach., Balk. myjy, Tat. mi, Kaz. bejit, Uzb. mija "brain", Trc., Tur., Turkm., Tat., Kaz., Kyrg. bal, Chuv. pyl "honey". Primary $m$ could be transformed into Turkic languages in $b$ and back or in $p$ in Chuvash.

Semantic field: "food", "fat", "brain", "liver", "kidneys", "honey", "deer, elk".

(4) Indo-European languages: $m a-, m e-$, etc.

Ind. mēdas- "fat", majján, majjấ, majjas- "brain", māimsá-, Goth. mimz, Slav. męso, Toch. misa, and others similar "flesh", Av. mazga- "brain", Ind. mádhu-, Arm. metr, Alb. mjal, Lith. medùs, Lat. mel, mellis "honey", Lat. mulgēre, Lith. milžti, OHG. melchan, Slav. mlěsti, and others similar "to milk".

Semantic field: "meat", "brain", "honey", "milk".

(5) Finno-Ugric languages: $m a-, m e-$

Veps, Est. maks, Mord., Fin. maksa, Sami mü̈kse, Udm., Komi mus, Mansi majt "liver", Fin. marja, Est. mari, Mari mör, Mansi morax "berry”, Fin. mäti, Mari mortn'o, Udm., 
Komi myz', Khan. märän, and others similar "caviar", Fin., Est. mesi, Mari, Komi ma, Udm. mu, Hung. méz, Mansi mag, and others similar "honey", Udm. mös, Komi, Khan. mes, Mansi mis "cow", Veps maid, Fin. majto, Sami majjt, and others similar "milk", Fin. mehu, Est. mahl "juice".

Semantic field: "liver", "berry", “caviar", "honey", “milk”, "juice”, “cow”.

The meaning of modifications of the phonostems ma-, me- in all languages as "prey, food" ("meat", "liver", "kidney", "fat", "brain", "honey", "bread", "sheep", “deer", and others) is clearly defined. The preservation and maintenance of life was the basic instinct for primitive man, and it is not surprising that his first words took on just such a meaning. At the same time, the meanings of the same phonostems were directed to the informational-signal side, and over time they spread to mental activity closely related to the language. Let us consider the examples.

(6) North Caucasian languages: $m a-, m e-\rightarrow n i-$, etc.

Chech., Ing. mott, Avar. mac, Bagv. miš, Cham. mič, Bezh. mic, Lez. mez, Udi muz “tongue", Bezh. nisal, Hun. nisa "to say", Ub. maša, Lak maq "word”, Akhv. mačunula, Bot. masi "to tell", Bats mottar "to seem", Ad. maqe, Kab. maq "voice", Cham. māna "to

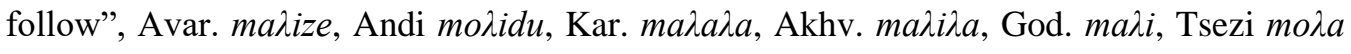
"to teach".

Semantic field: "language", "word", "to say, tell", "to seem", "voice", "to follow", "to teach".

(7) Kartvelian languages: $m a-$, me- $\rightarrow$ ene-, $n e-, n i-$, etc.

Georg. ena, Ming. nina "language", Laz nena "word", Svan li-mqer-i "understand", Georg. makhsovs "to remember", morčileba, Laz meudž-u "obey", Georg. martva "to order", Ming. meturapa "imitate", Georg. močvendeba "to seem".

Semantic field: "language", "word", "to understand", "memory", "to seem", “to obey", "to order".

(8) Turkic languages: $m a-\rightarrow$ be-, em-, etc.

Gag. belli, Turkm., Tur., Karach., Balk., Kaz., Uzb. belgi "sign", Turkm. magtamak, Tat. maktanu, Uzb. maqtamok, Kyrg. maktoo, Yak. maxtan "to praise", Turkm. üm, Kaz. ym, Tuv., Khak. im "sign, signal".

Semantic field: "sign, signal", "to praise".

(9) Indo-European: ma-, men-, mereĝ-, emen-, en(o)mn-, nōmn-, etc.

Gr. mепио̄ "to indicate", Lith. mó-ju, mó-ti, Slav. machati "to wave, hand sign", Ind. mahati "to appreciate, respect", Ic. mark "sign", Ind. mánas-, Av. manah- "sense", Ind. mányatē, Av. mainyeite, Slav. mbniti "to think", Lat. memǒrāre "to remember", Ind. mēếá, Arm. i-manam "to understand", Slav. modrb "wise", Alb. emën, Slav. jbmę, Ind. náma, 


\section{Valentyn Stetsyuk}

Arm. anun, Lat. nōmen, Ger. Name, Goth. namo, and others similar "name".

Semantic field: "sign", "give a sign", "to respect", "sense", "to think", "memory", "name".

(10) Finno-Ugric: ma-, man-, nem- etc.

Sami muone "to name", Mari manaš, Hung. mond, and others "to tell", Est. nimi, Sami namma, Udm., Komi nim, Khan. nem, Mansi näm, and others similar "name", Veps mel', Fin. mieli, Sami. miella "sense, reason", Udm. mylkyd "mood".

Semantic field: "to speak", "to thought", "name", "sense", "memory".

According to the common semantic field of all languages, we can conclude that the phonostems $m a-, m e-$, and their modifications developed in the root word from the meaning "sign, signal" to such categories as "word, name", "to name", "to speak", "to mark with". Then they developed in one direction "sense, meaning, think, reason", and in the other direction "to value, respect, honor".

In the study of root structures, Melnychuk (1991:28-29) drew attention to the functional and parallelism of root consonants being near articularly in phenomena of type I.E. "ghabh-/kap-lap-(ep-) "to grab, seize, take". Similar parallelism of consonants can be found also in languages of other families. They can be based on sounds that are involuntarily emitted by a child during actions that require certain efforts. Labor activity of an adult person was also accompanied by similar sounds when doing heavy work. For example, a person quacks, makes a sound of complex articulation at sudden movements during tree felling. Different people can have it differently, but in its composition has always a stop velar. The initial sounds, when forming a word characterizing such work, took the form of $g, k$ or $\check{c}$ transformed out of $k$. The development of semantics led to the formation of words with the meaning "sharp" and to the names of sharp tools and work with them.

5.1.4 Phonostems ka-, ča-, če-. Their possible modifications and divergences

(1) North Caucasian languages: $\check{c} a-, k a-$, $\check{c} e-$, etc.

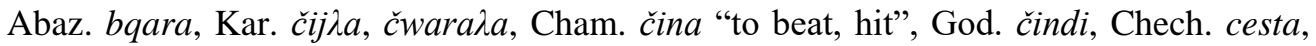
Tsak. qaxas "to cut", Avar. kotiza, Kar. čirala "to hack", Ub canišw, Bezh., Hun. čit, Lak čila, Ag., Rut. kant "knife", Cham. kota, Tsak. kira "ax", Ab. a-car, Abaz. cara "sharp".

(2) Kartvelian languages: $k e-, \check{c} e-, c e-$, etc.

Georg. cema, Svan li-qer "to beat, hit", Ming. čkirua, Laz o-čkir-u "to cut", Georg. kapva, Ming. kvatua "to hack", Ming. kvaga "ax", Georg., Ming. cel-i "scythe", Svan kucaj "sharp".

(3) Turkiv languages: $\check{c} a-, k a-, k e-$, etc.

Turkm. çapmak, Tat. çabu, Kaz. šabu, Uzb. čopmoq, Tuv. šavar, and others similar "to hack", Chuv. kas, Kaz. kesu, Uzb. kesmoq, Kyrg. kesuu, and others similar "to cut", Turkm. 
çaqmak, Tat. čagu, Uzb. çaqmok "to prick”, Turkm., Uzb. kesgir, Gag. keskin, and others similar "sharp".

(4) Indo-European languages: kāu-, kau-, kes-, (s)ker-, etc.

Ind. śấsti, śáśati, Ic. scera "to cut", OHG. sceran "to cut off", Gr. keirō "to shave", Lat. cūdō, -ere, Lith. káuju, kóviau "to hit, bump", Toch. kot-, kaut- "to prick", Slav. kujo, kovati "to beat, forge", Let. cirvis "ax".

(5) Finno-Ugric languages: $k o-, k e-, k i-$, čz-, etc.

Fin. kolista, Est. kolkima, Mari kopkaš, kyraš, čačaš, Udm. kyryny, kokany, Komi kotškyny, Khan. čaqalta "to beat, knock", Udm. korany, Komi keravny "to hack", Hung. kés, Mari küzö, Khan. kösag "knife".

Common semantic field: "to beat, hit", "to cut", "to hack", "knife", "ax", "sharp".

\subsection{Asian languages}

The patterns of development and transfer of bilabial consonants in Asian languages have not yet been established, therefore, the whole lexical complexes containing initial bilabial phonostems was divided according semantic fields, taking into account the experience of European languages.

5.2.1 Semantic field: "to be, to exist", "to bear, to be born", "to grow"

The structure of this semantic field includes such concepts as "ancestors" ("grandfather", "grandmother", “old woman"), "parents" ("father", "mother", "husband", “man", "women"), “old, senior", "family, kin", "child" ("young”, "young animal”, "boy", "girl”, "son”, "daughter", "servant”), "relative” ("nephew”, "brother", “cousin”, “niece”, "son-inlaw", "daughter-in-law"). They evolve into lower level concepts - "leader, lord", "head", "to lead, drive", "shepherd", "to take care of", "god", "priest", "rich" ("abundant", "much", "many", "very"), "strong, hard", "to take-give", and further "plant", "flower", "tree", "twig", "root", "grass".

(1) Sino-Tibetan languages. Phonostems $a b-, b a-, b h a-, m a-, p a-$. and their possible modifications.

Tib. ãbru "grain, seed", ãbray "to bear, bring forth, give birth", Burm. up "to rule, govern", Kach. up "to preside over, to rule", Lush. op "to rule, govern", Tib. a aba "magician, sorcerer, conjurer", Chin. "ba? "father; old man", "b_ar "abundant", " $p \bar{a} \eta$ "very, much", "b_āy "forceful, overbearing", "b_zn "ram, goat", Lush. bul "root", Lush. berām "a sheep", Lush. bar, Burm. pranh "very, much", Burm. pajh "bean", phwah "bear, be born", Lush. piay "to be born, come into being", Kach. phun "tree, bush, a stalk", Burm. pwij- "to hold, embrace, take into arms", Lush. phur "to bear", Chin. "pa "man", Kir. boku "husband", Lush. pay-pār "a flower", Kir. bhu "tree", Tib. pha -pa, -po "male, man" (affixes), Kir. bocu "husband", Tib. a-pha, pha, Lush. pa, Kir. pap "father", Tib. pho "man, male", Burm. pijh, Lush. pe (pēk) "to give", Tib. phji, Burm. phijh, Lush. pi "grandmother", 


\section{Valentyn Stetsyuk}

Tib. $b u$ "son, child", Kir. " $p u$ "bird, chicken, young of bird", Chin. "bōk "servant, follower", Tib. phrug "a child, a young one", ãbrog-phrug "boy", Kach. wa "man, male", Tib. may "much", Burm. mayh "king", Lep. món "much, many", Lush. māk-pa "a sister's or daughter's husband", Kir. "mer "to ripen", "to become fat", Lep. myók "a bridegroom, a son-in-law", Kir. moksi, mokcu "a son-in-law", Lush. mi "a person, a man", Kir. min "a person", Bur. minh-ma "woman, wife", Lep. mit, a-mit "a female", Kir. misś "wife", miśsmur "woman", Tib. mo "woman", Lush. mo "a bride, daughter-in-law", Lep. ku-mo "a lady", Chin. "mā? "mother", Tib. ma "mother", Burm. maj "mother", Lep. mo, a-mo "mother", Kir. mam "mother", Chin. " min "people", Tib. mi "man", Burm. mawh "give birth".

(2) Mongolic languages. Phonostems $a b-, a m-, b a-, b u-, m a-, p a-$, and their possible modifications.

Mong. $a b u$, Bur. $a b a-$, Kal. $a w$ - "to take", Mong. $a b u$ "paternal uncle", Bur. aba-, Kal. äwe- "father", Mong. amban, Bur. amba, Kal. ambn "big, large, official", Mong. obu, Khal. ovog, Bur obog "clan, family", Mong. ebei, Bur. abi, Kal. ewe "mother", Khal. bacgan, Bur. basagan "girl", Mong. baya, Kal. bayə, Bur., Khal. baga "young", Mong., Khal. balčir, Bur. balšar, Kal. balčir "infant", Mong., Khal., Bur. bari "to take", Mong. barlu, Khal. barlag "servant", Mong. batu, Bur. bata, Kal. bate "hard", Mong. Bur. beje, Khal. bije "body, person", Mong. buke "strong", Kal. beke, Bur. bexi "firm, hard", Mong., Bur. beri, Khal. ber "daughter-in-law, bride", Mong. bira u, Bur. burū, Kal. bürü "calf", Mong. bo, Mong. bo 'ol, Khal, Bur., Kal. bōl "servant", Mong., Khal., Bur., Kal. bol- "to become", Middle Mong. bue, Bur., Kal. bī "to be", Mong. bülü, Khal. bül, Bur., Kal. büle "cousin", "niece", Mong., Bur., Kal. mana "to graze, guard", Mong. mendü, Bur., Kal. mende "sane, healthy", Mong. mömü, Khal. mōm, mōmō "female breast".

(3) Tungus-Manchu languages. Phonostems $a m-, a w-, b a-, m a-, p a-$, and their possible modifications.

Ev. awus "husband of elder sister", Even āwus "husband of father's or mother's younger sister", Nan. aosi, Ulcha ausị "brother-in-law, son-in-law", Man. amba "big", Nan., Ulcha

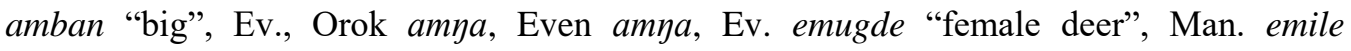
"female", Nan. emxe "mother-in-law, Neg. epa "father's elder brother", Man. efu "elder sister's husband", Oroch epere "grandfather", Ulcha, Orok, Oroch upa, Nan. opa "flour", Ev., Ulcha baldi, Ev. bald- "to bearn, be born", Ev., Neg. beje, Even, bej, Ev., Ulcha, Nan. bener, Neg. bene "younger relative-in-law", Man., Ev., Even, Ulcha, bi, and others similar "to be", Ev. burgu, Neg. bojgo, Nan. bujgu, and others similar "fat, thik", Man. bu, Ev., and others similar $\mathrm{r} b \bar{u}$ "to give", Ev., Even, Ulcha, Orok. and many others $m \bar{o}$ "tree", Ulcha puli, Orok pulu, Nan. polo, Ev. hula "ash tree, asp tree, poplar", Ev. maya, Even mayna-, Neg. mayg-, and others similar "matchmaker", Ev., Neg., Nan. majin, Even majis 
"protecting spirit", Orok, Nan. masi "strong, hard", Man., Nan. meme "female breast", Man.

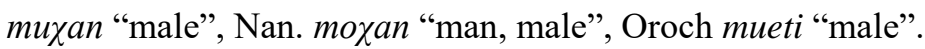

(4) Japanese Language. Phonostems am-, wa-, ma-, pa-, and their possible modifications.

Old Jap. amane- "plenty", opo- "big, many", opomono "food", waka- "young", warapa "child", wo(nokwo), wotokwo "man", womina, mije "woman", matur-wija, wogam- "to worship", wor-, wi "to be", Middle Jap. makanaf- "to feed", Old Jap. mamwor- "to guard, protect", pa "leaf", pana "flower", papa "mother", papuri "priest", pjito "man", pu "growth", puru- "old", um- "to bear", Middle Jap. mùkó "son-in-law, bridegroom", mus"to be born", musu-me "girl", woto-mje "girl".

(5) Korean language. Phonostems ab-, am-, ma-, pa-, pha-, and their possible modifications.

Modern Kor. abəži "father", am "woman, wife, female", ebeni "parents", mat "the eldest", mān, muri "many", mari "head", mom "body", mòní- "to graze", pä- "to be pregnant", pam "chestnut", pe-n-namu "birch", padil "poplar, willow", phuri "grass", piroso "beginning", poyori "bud", p:uri "root", pho "many", piegari "chicken", Middle Kor. psi "seed", psirkei "liver", namu "tree".

5.2.2 Semantic field: "prey, food" ("fat", "harvest", "grain", "meat", "liver", "kidney", "fish", "deer", "elk", "ram", "goat", "fat", "sheep", "honey", "milk", "bread", "gruel", "beans", and others), "tasty, sweet".

(1) Sino-Tibetan languages

Chin. "bəj, "b(h)ay "fat", Kach. ma, mam "paddy", Lush. mam "paddy, rice, food", Tib. mar "butter, oil", Kach. səman "leaf-lard", Chin. $m(h) \bar{a} n$ "eel", Chin. " $m_{-} \bar{e} j$ "fawn", " $m_{-} r i j$ "a kind of deer", Lush. be "a kind of edible beans", Chin. "mhīj? "rice", Burm. mun? "bread", Lush. hmor-hāy, Lep. jă-mór-zo "a species of rice".

(2) Mongolic languages

Khal., Ordos amsa- "to tate", Khal. bog "small cattle", Mong. buda'an, Khal., Bur. budā "gruel", "food", Mong. basina, Khal. bašinga "a kind of fish", Mong. miga-, Khal. max-, Bur. m'axa-, Kal. maxen "meat".

(3) Tungus-Manchu languages

Ev., Even, Neg. amt- "to taste", Even māja "food store", Man. malay-, Ulcha mala, Nan. malangu "plant oil", Ev., Neg. mandaksa "elk", Ev. mulkān, Even mulqan "deer", Neg. mosin, Man. musi, Ulcha mosi, Nan. musü "several foods".

(4) Japanese language

Old Jap. abura "fat", ama- "tasty, sweet", Middle Jap. ipij "boiled rice", iwo "fish", Middle Jap. makanaf- "to feed", Old. Jap. mame "bean", misó "a kind of thick bean gruel", 


\section{Valentyn Stetsyuk}

Old Jap. mwomwo "peach", mugji "wheat, barley", pada "flesh", pjituzi "sheep", pisipwo "a kind of bean paste", wi "pig".

(5) Korean language

Modern Kor. əpčin "beef", ma "potato", marim "edible seaweed", mat "taste", megi "trout", mek- "to eat, drink", meru "grapes", mès "wild apple, cherry", "mil "weat", misi "gruel", spčin "beef", pha "onion", phat "beans, peas", we "melon", pa "pear", pap "food", palgayi- "carp", piut "mackerel", pje "rice", pul "kidney", pok "swellfish", pori "barley".

5.2.3 Informational-signal and mental semantic field: "sign", "call", "name", "find", "instruct", "think", "look", and others similar

(1) Sino-Tibetan languages

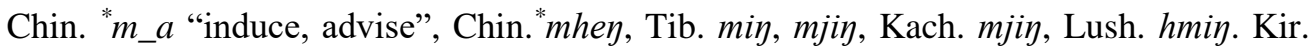

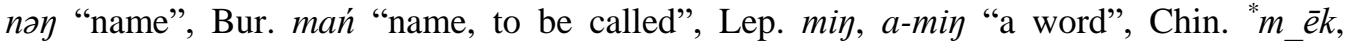
"m_rēk "to look on, examine", Tib. dmigs "to fancy, to imagine; to think", Kach. mjit "to mind, thought", Chin. "smārs "to instruct", Kach. mu "to see, behold", Lush. hти "to see, find", Kir. "min "think".

(2) Mongolic languages

Mong. möče-, Bur. müšxe-, Kal. möč - "to examine, investigate", Mong., Bur., Khal., Kal. mede "to know", Khal., Bur., Kal. im "sign", Dagur wal- "to find".

(3) Tungus-Manchu languages

Ev. baka-, Even baq-, Neg. baxa, Ulcha, Orok bā "to find", Man. mužin, Ulcha, Orok, Nan. muru "thought, mind", Nan. murū, Oroch muči "to think", Man., Ulcha, Orok, Nan. mute "can, be able".

(4) Japanese language

Old Jap. matwop- "to hesitate", wasur- "to forger", wosipa- "to teach", wotu-, utu-tu "reality", omop- "to think", manab- "to learn", wakar- "to understand", matwop- "to hesitate", Middle Jap. mòtòma- "to ask, demand".

(5) Korean language

Modern Kor. $m \bar{a} l$ "speech", $m \bar{a} l$ - "to avoid", mit- "to believe", musep- "to be afraid", mori- "to be unable", mut "to ask", para- "to desire", pāu- "to learn", puri "to call", poram "sign", puri "to call", Middle Kor. pti- "to follow".

5.2.4 Common semantic field: "to cut, hack", "chop", "to break", "to shear, scrape", "sharp", "sharp instrument"

In this semantic field, initial phonostems are more uniform ( $\mathrm{ka}-, \check{c} a-$, and their modifications) than in previous.

(1) Sino-Tibetan languages: $k u-, \check{c} a$ -

Chin. *'́rām? "to cut off, cut down", Tib. gcab "to cut small, to chop", Lush. čap "to trim, adze", čan "to cut up", Burm. kunh, Lush. kūr "to work hard, to make efforts". 
(2) Mongolic languages: $k a-, c a-, c ́ c-, \check{c} a$ -

Mong. qaji-, Bur. xaj- "to cut, hack", Middle Mong. qaqal-, Khal. xaxa-, Bur. xaga- "to break, tear off", Mong. qasu-, Khal., Kal kas-, Bur. xaha- "to cut off pieces", Mong. kirya-, Bur. xirga-, Kal. kiryə- "to shear", Mong. kutiza, Khal. kutga, Bur. xutaga "knife", Mong. kurča, Khal, xurc, Bur. xursa "sharp", Middle Mong. xajiči, Khal. xajč, Bur. xajša "scissors", Middle Mong. čabči, Khal. čavči, Bur. sabša "to chop, mow", Middle Mong. čaqi, Khal. caxi, Bur. saxil "to strike fire", Middle Mong. čalir "sharp", Khal. salir "sharp", "sharp instrument", Bur. sali-l "to be sharp", Kal. cale "sharp", calr "sharp instrument".

(3) Tungus-Manchu languages: $k a-, c a-, c ́ c a-, \check{c} a-$

Ev., Even, Ulcha, Nan., and others similar alt- "to split", Ev. keli "knife", Orok, Nan. keli "to cut", Even kotqān, Neg. kotko, Nan. qoto, Solon koto "knife", Ev. kuwa, Neg. kowa "to plane", Orok kuwai "plough", Ev. čali "arrow head", Neg. čōli "to cut off”, Man. čoli, Ulcha čălu, and others similar "to cut", Ev., Neg. čapka, Ulcha, Orok. čapqa, and others similar "fish spear", Ev. čiwuke, Nan. čioqo "awl”, Ev. čikā, Even čiqi, Neg. čixa "to cut", Ev. čôk-, Even čuk- "to dig", Neg. čok "to gauge".

(4) Japanese language: $k a-, k i-, k u-$

Old Jap. kedur- "to scrape off, kama "sickle", kar- "to shear, mow", kak-, Middle Jap. kàsù-r-, kosoga- "to scrape", Old Jap. katana "knife", kor-, kjir- "to cut", "to chop, hack", kji "notch", kjiri "drill, awl”, kug(j)i "nail, peg, hook", Middle Jap. kúfá "hoe, mattock", kur- "to delve", Old Jap. kururi "an arrow", Middle Jap. kúsàfi, kúsàbì "wedge, brace, clinch".

(5) Korean language: $k a-$

Modern Kor. kawi "scissors", kari- "to divide, split", k:ak- "to cut, trim", kik- "to shear, scrape", khal "knife", čha- "to kick", Middle Kor. čări- "to cut off, chop off".

5.3 Semantic field: "water", "flow", "river"

If the considered phonostems can be primary, then the sounds of the next verbal signals in turn is difficult to determine. It may be possible to suggest a solution in the observation of the development of children's language, but another way is possible, namely, the search for similarly sounding words in the semantic fields of the languages in question, derived from words that could be among the most used by primitive man. Such can be "water", "fire", "light", "sun", "heat" and light", etc.

When considering the words of the semantic field "water", "source", "river", "stream", "drink" and others, it turns out that many of them start with the sound $l$ in combination with vowels, i.e. $l i$-, $l e-l a-$, etc. If we also consider words with the meaning "wet", "puddle, swamp", "snow, rain", "pour, flow, run", etc., then it turns out that many of them also begin with $l i-, l e-, l a-$ :

(1) North Caucasian languages 


\section{Valentyn Stetsyuk}

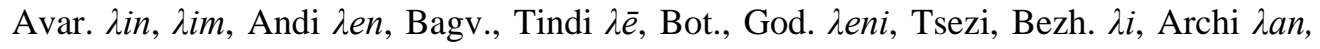
and others similar "water", Tsezi labu, Hin. laba, Ag. läpe, Tsak., Rut. lepa, Khin. läpä,

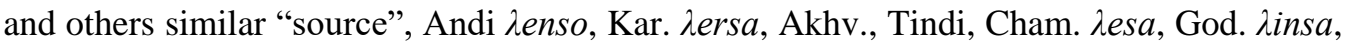

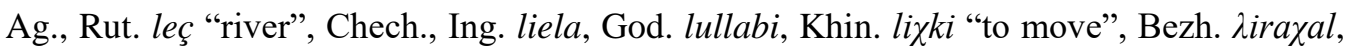
Lak lečin "to run", Avar. Aar "stream", Ab. a-las, Abaz. lasi "fast", Chech. lūo, Ing. loa "snow".

Semantic field: "water", "source", "stream", "marsh", "move, run", "fast", "snow".

(2) Kartvelian languages

Svan lic "water", Georg ru (out of "lu?) "stream", Svan lamb "wet", Ming. lenčq-i "swmp", Georg. lud-i "beer".

Semantic field: "water", "stream", "wet", "marsh", "beer".

(3) Turkic languages

The modern Turkic languages have very few words beginning with 1 . The initial 1 in most of them transformed into other sounds, it retained only in the Chuvash language preserving the most archaic features of Proto-Turkic. Chuv. lăm, Tur. nem, Tat., Kaz. dym, Kyrg. nym "moisture", Chuv. lüške "to puor, gush", lăs "drizzle", laš "imitation of the noisy splash of poured liquid".

Semantic field: "moisture", "to pour, gush", "wet".

(4) Indo-European languages

Arm. lič "swamp", Old Fris. lind, Slav. luža "puddle", Lith. liūgas "slush, bog", Old Ir. lind "liquid, drink", Slav. liti, Lith. lieti "to pour", Old Ic. lekr "estrus", Gr. leimōn "water meadow", loō, Lat. lavāre "to wash", Alb. lot "tear", Ir. lō-chasair "to drizzle", Old Ic. lìð "beer".

Semantic field: "swamp, puddle", "to pour", "to wash", "rain”, "tear", "leak", “drink, beer".

(5) Finno-Ugric languages

Fin., Est. laine, Veps lainiž, Mord. laj "wave”, Fin. lammiko, Est. lom, Hung. lö, Khan. läg "pool", Fin. lampi, Est. lamm, Sami lamm'p, Mansi lopsi, and others similar "swamp", Mord. lopodems "to wet", Mari lypka, Udm. lut'mem "wet", Komi log, Sami lüxxt, Mansi lox "bay", Fin., Est. lumi, Mord. lov, Mari lum "snow".

Semantic field: "wave", "puddle", "marsh", "bay", "wet", "snow".

For the semantic field "water", "river", and others similar in Asian languages, not a single word was found that has the phonostem la-, le- or similar. This fact casts doubt on the possibility of the general kinship of all the languages of the world, as Melnychuk (1991:33) confidently spoke of, seeing the isomorphism of internal structures in the repeated etymological complexes. 


\section{Reasoning on the Origin of the Human Language}

\section{The role of imitation in the process of language formation}

The fact of the presence of phonostems with bilabial consonants at the beginning of words of some common semantic fields of Asian and European languages can only say that just they were the first sounds of a human because of the peculiarities of his articulation apparatus, being common to all human races. Further development of the language is connecter with certain psychological characteristics of distinct human societies, connecting ideas about the world around with its reflection language, but having one common feature.

French sociologist Tarde argued that all social life largely bases on the instinct of imitating of individual persons to each other and devoted a lot to the evolution of human tongue in their work. In particular, he wrote:

Linguistic progress is always made firstly through imitation, then the struggle of two languages or dialects, as well as the struggle between two expressions or two figures of speech corresponding to the same meaning (Tarde, 2011:133).

When a language becomes established, imitation provides its communicative feature, i.e. mutual understanding between people due to the involuntary standardization of sound signals. That struggle written by Tarde provides the choice of the best option, inevitably associated with the loss of less expressive, less convenient for pronunciation, etc. Namely this character of the language complicates the reconstruction of its development.

Closely connected with nature, primitive man imitated not only his own kind, but also animals. The most developed of them monkeys express their various feelings with sounds, sending signals to each other about danger or the availability of food. Researches of primatologists convincingly testify that in the field of communicative behavior between higher primates and man there is a noticeable continuity (Vishnyatskiy, 2002:48-49). Accordingly, some of the sound signals of a person should have been as inarticulate as the sounds made by animals. Such assumption looks all the more logical if we proceed from the fact that man descended from some unknown primate species, although in general the variety of sounds in humans is richer than in animals due to a more perfect voice apparatus. This idea is not new, even I. Herder and J.-J. Rousseau imagined the development of human tongue based on onomatopeia, imitation of natural sounds, though Max Müller (1823-1900) was critical of such a presentation and ironically called it "bow-wow theory". Later linguists were not so categorical, and recognized that imitation played a significant role in the process of language evolution, as we can see from the example of Tarde. Over time, the significance of onomatopeia for expressive means of the language will increase more:

Onomatopoeia acts as the first step of linguistic expression, and is an important sign of quasi-language evolving into real language (i.e. languagization). (Ma Qinghua, 2018:43) 


\section{Valentyn Stetsyuk}

In his paper, Ma Qinghua conducts an extensive analysis of the means of onomatic and concludes that it still continues to maintain the deep nature of the language beyond the language system:

Substantial non-onomatopoeias come from onomatopoeias either directly or indirectly, including nouns, verbs and adjectives, consist of the majority of lexis. In addition, the model of onomatopoeia structures can be deemed as an imitative target or a structural meme of other models of non-onomatopoeia structures. Many non-onomatopoeias still carry onomatemes to various degree and manners, among which the imitation of all human sounds and some sounds of external world possess a linguistic universality (ibid:59).

Based on this, we can conclude that on the first stage of the formation of the language onomatopoeia played an even greater role. In many ancient languages aspirates $b h, d h, g h$, $t h, k h, g u h, q u h$, affricates $d z, t s, p s, k s$, labialized consonants $g u, q u, t u, p u$, trilled affricates $r z, r s, l \check{z}, l \check{s}, r z, r s, l \check{z}$, ľs, which could be an imitation of animal sounds but later on in many cases went through a simplification process.

Distinct consonants, as was shown by the example of sounds $m, n, t, t h, d, d h$ can have the simplest meaning. Also, other consonants, such as $k, k h, g, g u, r, r z$, and moreover combinations of consonants can be used for other meanings. This is a big topic that requires separate research, because it is noticed that,

the first consonant of any word in any alphabetic written language is an iconic Semantic key for the meaning of the whole word, much as the semantic portion or "radical" of many Sino-Japanese compound characters gives a clue to the meaning of the compound character (Zev Bar-Lev, 2016).

Unlike animals, man has the ability to pronounce vowels. In combination with vowels, consonants formed the first syllables which provides variety of sounds, pronounced by man. They made it possible to reflect phenomena of nature in different ways accordant with the sounds of the surrounding nature in human societies, formed in different natural conditions. It determined the development of individual languages in their own ways.

\section{The role and importance of rhythm in languages}

Sounds made by animals do not form a rhythmic sequence. Also the period of absence of articulate human tongue is characterized by randomly chaotic realizations of the position of the articulation organs. Besides, the distribution of energy into the spectrum of sounds of primitive proto-tongue is also chaotic. Modern languages, on the contrary, have a fairly ditinct discrete set of both the position of articulatory organs and the distribution of energy in the spectra of phonemes. The human tongue has such feature as the presence of the rhythm of syllable stress (Shcheka, 1994:84). The appearance of the rhythm characters the occurrence of tongue. 
While learning the language intonology and developing this idea, the Russian scholar Shcheka reveals the existence of systems of rhythmic levels of speech. They form the intonation of the tongue and on their which basis the corresponding intonological units are determined: harmoneme (the vowel phoneme or syllable corresponds to it), tacteme (word), melodeme (word combination), intoneme (sentence) and composeme (text). Intonology also allows to represent the evolution of language as a process of consistently forming rhythmically levels, starting with the lower (syllable) and ending with the highest level of the text, on which there is a departure from the principle of rhythmic organization of speech (=writing). By other words, the language passed from the harmoneme with the alternate appearance of higher intonological units (ibid:92).

In accordance with the same principle, "ontogeny recapitulates phylogeny", Shcheka projects the stages of developing the linguistic ability of children on the stages of development of life on Earth and periodizes the chronology of the evolution of the language, referring the occurrence of syllogic rhythm to the birth of human tongue. According to his calculations, it originated 10.7 million years ago (ibid:92-94). Such an exact definition contradicts the assertion that Neanderthals, who lived much later, could not have a tounge in view of the inability to pronounce vowel sounds (see above). Similar contradictions show that the study of the origin of human language has to be conducted not by narrow specialists in different fields of knowledge but by the multidisciplinary approach.

\section{Conclusion}

The mystery of the origin of the human language is hidden in the language itself. Relevant data that can help uncover this mystery scattered across all the languages of the world and isolating them for research is not an easy task. All the languages of the world are a complex system formed by a large number of components that interact with each other in different ways. According to Jan Stewart, to describe the interaction of relatively simple components and the dynamics of similar systems, we need an exact mathematical theory, which will develop before 2050 (Stewart, 2002). However, the use of the mathematical apparatus will be possible if all the components of the language will be simplified as much as possible, structured in a certain order and compiled into a database. One of the classes of such components can be etymological complexes, the comparison of which is done in the proposed work.

\section{Appendix}

Abbreviation $\quad$ Full name

Abaz. Abaza
References

Klimov \& Khalilov, 2003

Klimov \& Khalilov, 2003 
Valentyn Stetsyuk

\begin{tabular}{|c|c|c|}
\hline Ad. & Adyghe & Klimov \& Khalilov, 2003 \\
\hline Ag. & Agul & Klimov \& Khalilov, 2003 \\
\hline Akhv. & Akhvakh & Klimov \& Khalilov, 2003 \\
\hline Alb. & Albanian & Pokorny, 1949-1959 \\
\hline And. & Andi & Klimov \& Khalilov, 2003 \\
\hline Arch. & Archi & Klimov \& Khalilov, 2003 \\
\hline Arm. & Armenian & Acharrjan, 1971 \\
\hline Av. & Avesta & Rastorguyeva \& Edelman, 2011 \\
\hline Avar. & Avar-Andean & Klimov \& Khalilov, 2003 \\
\hline Bagv. & Bagvalal & Klimov \& Khalilov, 2003 \\
\hline Balk. & Balkar & Sevortian, 1974 \\
\hline Bashk. & Bashkir & Sevortian, 1974 \\
\hline- - & Bats & Klimov \& Khalilov, 2003 \\
\hline Bezh. & Bezhita & Klimov \& Khalilov, 2003 \\
\hline Bot. & Botlikh & Klimov \& Khalilov, 2003 \\
\hline Bur. & Buryat & Starostin, 1998-2003c \\
\hline Burm. & Burmese & Starostin, 1998-2003e \\
\hline Cham. & Chamalal & Klimov \& Khalilov, 2003 \\
\hline Chech. & Chechen & Aliroyev, 2005 \\
\hline Chin. & Chinese & Starostin, 1998-2003e \\
\hline Chuv. & Chuvash & Skvortsov, 1985 \\
\hline - & Dagur & Starostin, 1998-2003c \\
\hline Darg. & Dargwa & Klimov \& Khalilov, 2003 \\
\hline Erz. & Erzya & Häkkinen, 2007 \\
\hline Est. & Estonian & Häkkinen, 2007 \\
\hline & Even & Starostin, 1998-2003d \\
\hline Ev. & Evenki & Starostin, 1998-2003d \\
\hline Fin. & Finnish & Häkkinen, 2007 \\
\hline Fris. & Frisian & Kluge \& Seebold, 1989 \\
\hline Gag. & Gagauz & Sevortian, 1974 \\
\hline Georg. & Georgian & Klimov \& Khalilov, 2003 \\
\hline- & German & Kluge \& Seebold, 1989 \\
\hline God. & Godoberi & Klimov \& Khalilov, 2003 \\
\hline Goth. & Gothic & Holthausen, 1934 \\
\hline Gr. & Old Greek & Frisk, 1970 \\
\hline Hin. & Hinuq & Klimov \& Khalilov, 2003 \\
\hline Hun. & Hunzib & Klimov \& Khalilov, 2003 \\
\hline Hung. & Hungarian & Zaicz, 2006 \\
\hline I.-E. & Indo-European & Pokorny, 1949-1959 \\
\hline Ic. & Old Icelandic & Cleasby \& Vigfússon, 1874 \\
\hline Ing. & Ingush & Klimov \& Khalilov, 2003 \\
\hline Ind. & Indo-Aryan & Pokorny, 1949-1959 \\
\hline Inkh. & Inkhoqwari & Klimov \& Khalilov, 2003 \\
\hline Ir. & Irish & Pokorny, 1949-1959 \\
\hline Jap. & Japanese & Starostin, 1998-2003a \\
\hline $\mathrm{Kab}$. & Kabardian & Klimov \& Khalilov, 2003 \\
\hline Kach. & Kachin & Starostin, $1998-2003 \mathrm{e}$ \\
\hline Kal. & Kalmyk & Starostin, 1998-2003c \\
\hline Kar. & Karata & Klimov \& Khalilov, 2003 \\
\hline Karach. & Karachay & Sevortian, 1974 \\
\hline Kaz. & Kazakh & Sevortian, 1974 \\
\hline
\end{tabular}


Reasoning on the Origin of the Human Language

\begin{tabular}{|c|c|c|}
\hline Khant. & Khanty & Zaicz, 2006 \\
\hline Khin. & Khinalug & Klimov \& Khalilov, 2003 \\
\hline Khw. & Khwarshi & Klimov \& Khalilov, 2003 \\
\hline Khak. & Khakas & Sevortian, 1974 \\
\hline Khal. & Khalkha & Starostin, 1998-2003c \\
\hline Kir. & Kiranti & Starostin, $1998-2003 \mathrm{e}$ \\
\hline - - & Komi & Lytkin \& Guliayev, 1970 \\
\hline Kor. & Korean & Starostin, 1998-2003b \\
\hline Kyrg. & Kyrgyz & Yudakhin, 1965 \\
\hline Kum. & Kumyk & Sevortian, 1974 \\
\hline - - & Lak & Klimov \& Khalilov, 2003 \\
\hline Lat. & Latin & Walde, Hofmann \& Berger, 1965 \\
\hline & Laz & Klimov \& Khalilov, 2003 \\
\hline Lep. & Lepcha & Starostin, $1998-2003 \mathrm{e}$ \\
\hline Let. & Lettish & Fraenkel, 1955-1965 \\
\hline Lez. & Lezgian & Klimov \& Khalilov, 2003 \\
\hline Lith. & Lithanian & Fraenkel, 1955-1965 \\
\hline Lush. & Lushai & Starostin, $1998-2003 \mathrm{e}$ \\
\hline Man. & Manchu & Starostin, 1998-2003d \\
\hline & Mansi & Zaicz, 2006 \\
\hline- & Mari & Zaicz, 2006 \\
\hline Ming. & Mingrelian & Klimov \& Khalilov, 2003 \\
\hline Mok. & Moksha & Häkkinen, 2007 \\
\hline Mong. & Mongolian & Starostin, 1998-2003c \\
\hline Mord. & Mordvinic & Häkkinen, 2007 \\
\hline Nan. & Nanai & Starostin, 1998-2003d \\
\hline Neg. & Negidal & Starostin, 1998-2003d \\
\hline OE. & Old English & Holthausen, 1974 \\
\hline OHG. & Old High German & Kluge \& Seebold, 1989 \\
\hline-1 & Ordos & Starostin, 1998-2003c \\
\hline - - & Oroch & Starostin, 1998-2003d \\
\hline —— & Orok & Starostin, 1998-2003d \\
\hline Pers. & Persian & Rastorguyeva \& Edelman, 2011 \\
\hline PFU. & Proto-Funno-Ugric & Häkkinen, 2007; Zaicz, 2006 \\
\hline PIE. & Proto-Indo European & Pokorny, 1949-1959 \\
\hline PST. & Proto-Sino-Tibetan & Starostin, 1998-2003e \\
\hline PTM. & Proto-Tnugus-Man. & Starostin, 1998-2003d \\
\hline Prus. & Old Prussian & Pokorny, 1949-1959 \\
\hline Rut. & Rutul & Klimov \& Khalilov, 2003 \\
\hline S.-Alt. & South Altaic & Sevortian, 1974 \\
\hline- & Sami & Häkkinen, 2007 \\
\hline Sax. & Ols Saxon & Clark Hall, 1916 \\
\hline Slav. & Slavic & Trubachiov, 1974-2018 \\
\hline -— & Solon & Starostin, 1998-2003d \\
\hline - - & Svan & Klimov \& Khalilov, 2003 \\
\hline Tab. & Tabasaran & Klimov \& Khalilov, 2003 \\
\hline Tat. & Tatar & Sevortian, 1974 \\
\hline Tib. & Tibetan & Starostin, $1998-2003 \mathrm{e}$ \\
\hline- & Tindi & Klimov \& Khalilov, 2003 \\
\hline Toch. & Tocharian & Pokorny, 1949-1959 \\
\hline
\end{tabular}




\section{Valentyn Stetsyuk}

$\begin{array}{lll}\text { Tsak. } & \text { Tsakhur } & \text { Klimov \& Khalilov, 2003 } \\ -\_ & \text {Tsezi } & \text { Klimov \& Khalilov, 2003 } \\ \text { Tur. } & \text { Turkish } & \text { Baskakov, Golubeva, Kyamileva, et al., } 1977 \\ \text { Tuv. } & \text { Tuvan } & \text { Sevortian, 1974 } \\ \text { Turkm. } & \text { Turkmenian } & \text { Aliyev \& Borshev, 1929 } \\ \text { Trc. } & \text { Old Turkic } & \text { Nadeliayev, Nasilov, Tenishev et al., } 1969 \\ \text { Ub. } & \text { Ubykh } & \text { Klimov \& Khalilov, 2003 } \\ -- & \text { Udi } & \text { Klimov \& Khalilov, 2003 } \\ \text { Udm. } & \text { Udmurt } & \text { Lytkin \& Guliayev, 1970 } \\ -- & \text { Ulcha } & \text { Starostin, 1998-2003d } \\ \text { Uzb. } & \text { Uzbek } & \text { Yudakhin, 1957 } \\ -- & \text { Veps } & \text { Häkkinen, 2007 } \\ \text { Yak. } & \text { Yakut } & \text { Afanasiev \& Kharitonov, } 1968\end{array}$

\section{References}

Abayev, V. I. 1958-1989. Historian-Etymological Dictionary of Ossetic [M]. Moscow-Leningrad: Publisher of Academy of Science.

Acharrjan, H. R. 1971. Etymological root dictionary of the Armenian language [M]. Yerevan: Publisher not specified.

Afanasiev, P. S. \& L. N. Kharitonov (eds.). 1968. Russian-Yakut Dictionary [M]. Moscow: Soviet Encyclopedia.

Alatyriev, V. I. 1988. Etymological Dictionary of the Udmurt Language [M]. Izhevsk: Research Institute at Council of Ministers of the Udmurt Autonomous Soviet Socialist Republic.

Aliroyev, I. Yu. 2005. Chechen-Russian Dictionary [M]. Moscow: Academia.

Aliyev, A. \& K. Borshev. 1929. Russian - Turkmen Dictionary [M]. Ashkhabad: Publisher not specified.

Alpatov, I. M. 2006. Is Marr's Doctrine Actuall? [J]. The Questions of Linguistics, (1): 3-15.

Andreyev, N. D. 1986. The Early-Indo-European Language [M]. Leningrad: Nauka.

Bar-Lev, Z. 2016. Semantic Keys and Reading [J]. Macrolinguistics, 4(5): 1-10.

Baskakov, N. A., N. Golubeva, A. Kyamileva, K. Lyubimov, F. Salimzyanova \& E. Yusipova. 1977. Turkish-Russian Dictionary [M]. Moscow: Russkiy Yazyk.

Brükner, A. 1957. Etymological Dictionary of the Polish Language [M]. Warsaw: General Knowledge.

Bulakhovskyi, L. A. 1975. Sketches in Common Linguistics: Selected works in five volumes [M]. Vol.1. Kyiv: Naukova Dumka.

Burlak, S. A. 2007. The Origin of Language: New Materials and Researches [M]. Moscow: Institute of Scientific Information on Social Sciences of RAS (Russian Academy of Sciences).

Chomsky, N. 1972. Language and Mind [M]. Moscow: Publishing House of Moscow University.

Clark Hall, J. R. 1916. A Concise Anglo-Saxon Dictionary [M]. New York: The Macmillan Company.

Clauson, G. 1972. An Etymological Dictionary of Pre-Thirteenth-Century Turkish [M]. Oxford: Clarendon Press.

Cleasby, R. \& G. Vigfússon. 1874. An Icelandic-English dictionary [M]. Oxford: Clarendon Press.

Edelman, D. I. 2011. Etymological Dictionary of Iranian Languages [M]. Vol. 4. Moscow: Publishing Firm "Eastern literatur" of RAS (Russian Academy of Sciences).

Fortunatov, F. F. 1956. Language and Dialects: Selected Works [M]. Moscow: State Teaching and Pedagogical Publishing House of the Ministry of Education of the Russian Soviet Socialist Republic.

Fraenkel, E. 1955-1965. Lithuanian Etymological Dictionary [M]. Heidelberg: Carl Winter.

Frisk, H. 1970. Greek Etymological Dictionary [M]. Heidelberg: Carl Winter.

Häkkinen, K. 2007. Etymological Dictionary of Present-Day Finnish [M]. Helsinki: WSOY.

Holthausen, F. 1934. Gothic Etymological Dictionary [M]. Heidelberg: Carl Winter.

Holthausen, F. 1974. Old-English Etymological Dictionary [M]. Heidelberg: Carl Winter.

Klimov, G. A. \& M. S. Khalilov. 2003. Dictionary of Caucasus Languages [M]. Moscow: Publishing Firm 


\section{Reasoning on the Origin of the Human Language}

"Oriental literature" of RAS (Russian Academy of Sciences).

Kluge, F. \& E. Seebold. 1989. Etymological Dictionary oh the German Language [M]. Berlin-New York: Walter de Gruyter.

Lieberman, P. 1984. The biology and evolution of language [M]. Cambridge, Mass: Harvard University Press.

Lytkin, V. I. \& E. S. Guliayev. 1970. Short Etymological Dictionary of the Komi Language [M]. Moscow: Nauka.

Ma Qinghua. 2018. The Significance of Onomatopoeia in Languagization: From the perspective of sound-meaning relationship under dynamic system principle [J]. Macrolinguistics, 6(8): 43-62.

Marr, N. Y. 1936. Selected Works [C]. Vol. 2. Moscow-Leningrad: State Socio-economic Publishing House.16.

Melnychuk, A. S. 1991. About General Relationship of Languages of the World [J]. The Questions of Linguistics, (2): 27-42.

Meyer-Lübke, W. 1992. Romance Etymological Dictionary [M]. Heidelberg: Carl Winter.

Nadeliayev, V. M., D. M. Nasilov, E. R. Tenishev \& A. M. Shcherbak. 1969. Old-Turkic Dictionary [M]. Leningrad: Nauka.

Nikolayeva, T. V. 1996. The Theories of the Origin of Language and its Evolution. A New Direction in Modern Linguistics [J]. The Questions of Linguistics, (2): 79-89.

Pokorny, J. 1949-1959. Indo-European Dictionary [M]. Bern: Francke.

Rastorguyeva, V. S. \& D. I. Edelman. 2011. Etymological Dictionary of Iranian Languages [M]. Vol. 2. Moscow: Publishing Firm "Eastern literature" of RAS (Russian Academy of Sciences).

Rulen, M. 1991. Origin of Language: Retrospective and Perspective [J]. The Questions of Linguistics, (1): 5-19.

Sevortian, E. V. 1974. Etymological Dictionary of the Turkic languages [M]. Moscow: Nauka.

Shcheka, Y. V. 1994. Hypothesis about Possible Stages of Linguistic Evolution (On the material of the intonology of the Turkish language) [J]. The Questions of Linguistics, (1): 83-99.

Skvortsov, M. I. 1985. Chuvash-Russian Dictionary [M]. Moscow: Research Institute of Language, Literature, History and Economics at the Council of Ministers of the Chuvash Autonomous Soviet Socialist Republic.

Smirnov, S. V. 1997. Religion of Neanderthals: Arguments for and against [J]. Archeology, (1): 3-16.

Starostin, S. 1998-2003a. Japanese etymology [OL]. http://starling.rinet.ru/cgi-bin/main.cgi?root=config\& morpho $=0$.

Starostin, S. 1998-2003b. Korean etymology [OL]. http://starling.rinet.ru/cgi-bin/response.cgi?root=config $\&$ morpho $=0 \&$ basename $=$ datalalt $\mid$ koret $\&$ first $=1$.

Starostin, S. 1998-2003c._Mongolian etymology [OL]. http://starling.rinet.ru/cgi-bin/response.cgi?root= config $\&$ morpho $=0 \&$ basename $=\backslash$ datalalt $\mid$ monget $\&$ first $=1$.

Starostin, S. 1998-2003d. Tungus etymology [OL]. http://starling.rinet.ru/cgi-bin/response.cgi?root=config $\&$ morpho $=0 \&$ basename $=\mid$ datalalt $\mid$ tunget $\&$ first $=1$.

Starostin, S. 1998-2003e. Sino-Tibetan etymology [OL]. http://starling.rinet.ru/cgi-bin/response.cgi?root= config \& morpho $=0 \&$ basename $=\backslash$ datalsintib $\backslash$ stibet $\&$ first $=1$.

Stetsyuk, V. 1998. The Research of Prehistoric Ethnogenetic Processes in Eastern Europe [M]. Vol. 1. Lviv-Kyiv: Politychna Dumka.

Stewart, I. 2002. The Mathematics of 2050: The Next Fifty Years [M]. Edited by John Brockman. New York: Vintage Books.

Tarde, G. 2011. The Laws of Imitation [M]. Moscov: Academic Project.

Trubachiov, O. N. (ed.) 1974-2018. Etymological Dictionary of the Slavic Languages [M]. Moscow: Institute of Russian Language of the USSR Academy of Sciences.

Vasmer, M. 1964-1973. Etymological Dictionary of the Russian Language [M]. Moscow: Progress.

Velmezova, E. 2002. The "Arrested Evolution": Notion, theories, myth? [A]. History of Linguistics 2002 (selected papers from the Ninth international conference on the history of language studies) [C]. Amsterdam/Philadelpjia: John Benjamins Publishing Company, 27-30.

Vernadskiy, V. I. 2004. Biosphere and noosphere [M]. Moscow: Airis-Press. 


\section{Valentyn Stetsyuk}

Vishnyatskiy, L. B. 2002. The Origin of the Language: The Current State of the Problem (View of an archaeologist) [J]. The Questions of Linguistics, (2): 48-63.

Walde, A., J. B. Hofmann \& E. Berger. 1965. Latin Etymological Dictionary [M]. Heidelberg: Carl Winter.

Wind J. 1988. Language evolution and pedomorphosis [A]. In M. E. Landsberg (ed.). The genesis of language. A different judgement of evidence [C]. Berlin, New York, Amsterdam: Mouton de Gruyter. 137-144.

Yakushin, B. V. 1985. Hypotheses about Origin of Language [M]. Moscow: Nauka.

Yegorov, V. G. 1964. Etymologiacal Dictionary of the Chuvash Language [M]. Cheroksary: Chuvash Book Publishing House.

Yudakhin, K. K. 1957a. Russian-Kyrghyz Dictionary [M]. Moscow: State Publishing House of Foreign and National Languages.

Yudakhin, K. K. 1957b. Uzbek-Russian Dictionary [M]. Moscow: State Publishing House of Foreign and National Languages.

Yudakhin, K. K. 1965. Kyrghyz-Russian Dictionary [M]. Moscow: Soviet Encyclopedia.

Zaicz, G. 2006. Etymologiacal Dictionary. The origin os Hungarian Words and Suffixes [M]. Budapest: Könyvkiadó. TINTA. 